\title{
Comparative Analysis of Effects of Heavy Vehicles on Roads in Southern and Northern Nigeria
}

${ }^{1}$ Osadebe, C. C. and ${ }^{2}$ Quadri, H. A.

${ }^{1,2}$ Road Research Department, Nigerian Building and Road Research Institute, Ota, Ogun State, Nigeria.

Corresponding E-mail:dejiquadry@gmail.com

Submitted on: 20/01/2021;

Accepted on: $31 / 03 / 2021$

\begin{abstract}
The prevalence of flexible pavement deterioration in the country has been adduced largely by highway researchers to trucks or heavy vehicles carrying much in excess of permitted legal limits. This study investigated levels of deterioration of Abuja-Kaduna-Kano road (Northern region) and Port HarcourtEnugu road (Southern region) caused by heavy vehicles through a 14 day traffic counts conducted at 5 strategic points each in the Northern and Southern regions. Traffic data generated were analyzed with AASHTO Design Guidelines (1993) to evaluate Equivalent Single Axle Loads (ESALs) and Vehicle Damage effects on the road. The Traffic Volume, Average Daily Traffic (ADT), and Heavy Vehicle per day (HV/day) were estimated to be 2,063,977; 147,427; and 12,246 respectively in the Northern region, while in the Southern region they were estimated to be 750,381; 53,670; and 20,951 respectively. Motorcycles, Passenger cars, Mini-buses/Pick-ups, and Heavy vehicles constitute 18.7\%, 49.7\%, 23.3\% and 8.31\% of the total traffic volume respectively in the Northern region while in the South they constitute 4.6\%, 30.1\%, $26.2 \%$ and $39.1 \%$ respectively. ESALs were estimated according to AASHTO Design Guidelines in the Northern and Southern regions as 547,730 and 836,208 respectively. An average Load Equivalency Factors (LEFs) of 3.43 and 3.02 were estimated for each heavy vehicle plying the Northern and Southern roads respectively and this could explain some failures (alligator cracks, potholes, depressions, linear or longitudinal cracks along the centre line amongst others) inherent on the road.
\end{abstract}

Keywords: Flexible pavement deterioration, Traffic counts, Equivalent Single Axle Load (ESAL), Load Equivalency Factor (LEF).

\section{Introduction}

Pavement is an engineering structure placed on natural soils and designed to withstand the traffic loading and the action of the climate with minimal deterioration, and in the most economical way (Hudson et al., 2003; Pais et al., 2013). Every vehicle which passes over a road causes a momentarily small, but significant deformation of the road pavement structure. The passage of many vehicles has a cumulative effect which gradually leads to permanent deformation. Magnitude and configuration of vehicular loads together with the environment have a significant effect on induced tensile stresses within flexible pavements (Yu et al., 1998; Zumrawi, 2016). Heavy vehicle load on the pavements subjects them to high stresses causing damage. However, not all trucks have the same damaging effects; the damage on the road pavement depends on speed, wheel loads, number and location of axles, load distributions, type of suspension, number of wheels, tire types, inflation pressure and other factors (Gillespie et al., 1993; Savio et al., 2016; Raheel et al., 2018).

A flexible pavement combines layers of generally different materials in a structural system designed to withstand the cumulative effects of traffic and climate to the extent that, for a predetermined period, the foundation or Subgrade is adequately protected and the vehicle operating costs, safety and comfort of the road user are kept within tolerable limits (Mc Elvaney and Snaith, 2005). Pavements are designed to last for a specific number of years. However, the life of a pavement can be extended by carrying out appropriate maintenance. It is assumed that the pavement deteriorates due to repetition of the stresses, strains and deflections generated by traffic loads, ultimately reaching a terminal condition that necessitates strengthening. A number of factors can contribute to the failure or deterioration of a pavement, the aim of this paper however is to evaluate the damaging effects of heavy axles on flexible pavement in both the southern and northern Nigeria. 


\section{Statement of the Problem}

Traffic loading in terms of numbers and axle repetitions has shown to be one of the major causes of pavement failure. The failure of a flexible pavement is represented by localized depressions and heaving up in its vicinity. The sequence of depressions and heaving-up develops a wavy surface of the pavement and the settlement of any of the component layers of the pavement develops waves and corrugations or longitudinal ruts and shoving on the pavement surface (Kadyali and Lal, 2008; Pais et al., 2013; Savio et al., 2016; Titi et al., 2018; Raheel et al., 2018). Subgrade failure has been attributed mostly to excessive stress application from more load than designed, and inadequate thickness (Ndoke, 2013; Pais et al., 2013; Titi et al., 2018). The sub-base and base failures have been attributed mostly to the loss of cohesion or binding action under repeated application of loads. Finally, even the failure of the surface is attributed partly to traffic loading (Ndoke, 2013; Pais et al., 2013; Savio et al., 2016; Titi et al., 2018; Raheel et al., 2018). Since traffic loading is a recurrent factor in the failure of all the layers, there is therefore the need to look at the impacts of axle load on pavement failure (Ndoke, 2013; Savio et al., 2016; Titi et al., 2018).

Previous studies on road damage identified overloaded heavy vehicles as the primary cause of road pavement structure distresses, with service lifetime decreasing during design life time (Rahim, 2000; Koesdarwanto, 2004; Sulisty and Handayani, 2002 and Osadebe et al., 2013). The presence of overloading is indicated by the width area of rutting which is more than $60 \%$ of total road structural distress per $\mathrm{km}$ and by Maximum Axle Load (MAL) of the heavy vehicle which is larger than the standard MAL. Evaluation of the effect of heavy vehicle overloading to the pavement damage/service life on the road by Sulisty and Handayani (2002) concluded that because of overloading on the road, there was a decrease of 1.4 year design life or $28 \%$ of the original design life of 5years. The study on Road Pavement Failure by Osadebe et al. (2013) concluded that owing to high volume of heavy vehicles with high axle loading, the maximum allowable axle load limits in service along Port Harcourt-Enugu road exceeded the design provisions by as much as three folds which was highly responsible for the level of deterioration of the road. They added that trucks or heavy vehicles carrying much in excess of legal limits were largely responsible for deplorable state of the road. Incessant pavement failures in the country largely caused by heavy vehicles have deleterious effects on economy as safety of road users is threatened, lives are lost on constant basis, precious time is lost to traffic snarls caused as a result of poor states of the roads (Oduola, 2010; Osadebe et al., 2013; Tijani et al., 2017; Matawal et al., 2018). Based on the foregoing, this research work was embarked upon in order to substantiate the findings of previous researchers and to suggest a way forward.

\section{Material and Methods}

\section{Brief description of study area}

Abuja-Kaduna-Kano road is a dual carriageway flexible pavement that consists of asphaltic surface over compacted base and sub base courses. It lies on the latitude of $9^{0} 4^{\prime} 20.1504$ ' $\mathrm{N}$ and longitude $8^{0} 31^{\prime} 00.00^{\prime}$ 'E on the Northern part of Nigeria's High plains, North of Jos Plateau, in the Sudanian Savanna region that stretches across the South of Sahel (Matawal et al., 2018). The vegetation cover is Sudan Savannah type, characterized by scattered short basement complex igneous rocks, trees, shrubs and grasses. The soil is mostly loamy to sandy type and a substantial amount of clay is found too. The Port Harcourt-Enugu dual carriage way is a flexible pavement structure that consists of asphaltic surface over stabilized base and sub base. It is a part of the Trans-African highway. It is located within the geographical coordinates of between $4^{0} 45^{\prime}$ and $6^{0} 21^{\prime} \mathrm{N}$ and between $6^{0} 51^{\prime}$ and $7^{0} 30^{\prime} \mathrm{E}$. The vegetation of the area varies from mixed savannah to dense vegetation (Osadebe et al., 2013).

\section{Preliminary field investigation}

Field investigations of the carriageway, shoulders, drains, cuts, embankments, etc., were conducted in order to assess the structural conditions, extent of defects, deterioration or failure and identify major surface features which provided sufficient information for the detailed fieldwork. Most importantly, this exercise 
was embarked on in order to identify appropriate spots or locations where traffic counts could be administered along Abuja-Kaduna-Kano road and Port Harcourt-Enugu road. Consequently, 5 locations each in the northern and southern regions were chosen; Zuba (Abuja), Abuja junction (Kaduna), Jos junction (Kaduna), Gwargoje (Zaria), Kwankwasiya (Kano) in the northern region and Ndiagu Amechi, Ishiagu junction, Okigwe, Osisioma, Rumuigbo in the southern region.

\section{Field investigation}

Fourteen-day manual vehicle count was conducted using hand-tallies of visually observed vehicles to estimate the daily traffic and Average Daily Traffic (ADT) taken by direction. All counts taken have a data recording interval of one hour. All counts were also taken by direction and no count contains data collected within two days before and after any major holiday. The traffic survey was then conducted at five (5) count stations each along the two carriageways. Two enumerators with separate count forms were used all times - one for each direction of flow. The axle load survey was not conducted due to the absence of weighing bridges.

However, to quantify traffic loads on the test pavements, the heavy vehicles considered to cause structural damage to the pavement were given special attention. The three classes of vehicles categorized as trucktype (heavy vehicle) were considered in this study, in accordance with 1993 AASHTO Design Guide requirement. They are vehicle-class of $6 \mathrm{~B}$ for 2-axle trailer, 7A for 3-axle trailer and 7C for more than 3axle trailer. Vehicle-class 7C consists of three sub-classes; including 7C1 for 4-axle trailer, 7C2 for 5-axle trailer and 7C3 for 6-axle trailer. AASHTO Road test data for the load distribution of axle load as presented in Equation 1 was used to obtain the respective load equivalent factors for the damaging effect of the vehicle on the pavement. This process was repeated for all the categories of the vehicles that have damaging effect as analyzed in the traffic count (Rolt, 1981; Parsley and Ellis, 2003).

The traffic volume on the road was estimated in terms of Equivalent Single Axle Load (ESAL). An Equivalent Standard Axle is defined as "a Single Axle carrying a load of 80kN or 8.16 tonnes spread over two sets of dual tyres, each dual set separated by $300 \mathrm{~mm}$ (Parsley and Ellis, 2003). Light vehicles and passenger cars are not considered in estimating the damaging effect of the traffic loading on the road because of little or no damage impact they have on it. Axle loads were converted to ESALs using the "Fourth Power Rule". Vehicle Damaging Factor or axle load equivalency factor (LEF or E) of each heavy vehicle was determined using 1993 AASHTO Design Guide procedure, as follows.

$$
\mathrm{EF}=\left(\frac{\text { Axle Load }}{80 T N}\right)^{4}
$$

\section{Results and Discussion}

\section{Traffic characteristics of Abuja-Kaduna-Kano road}

The effect of heavy vehicles on flexible pavement was investigated using Abuja-Kaduna-Kano road as a case study, the summary of traffic characteristics on the road is presented in Table 1. It could be observed from Table 1 that a total of 2,063,977 vehicles were counted, indicating a total traffic volume on both directions. Motorcycles, passenger cars, mini-buses/pick-ups and heavy vehicles constitute $18.7 \%$ $(385,616), 49.7 \%(1,025,930), 23.3 \%(480,988)$ and $8.31 \%(171,443)$ of the total traffic volume respectively. The average daily traffic (ADT) and average heavy vehicles per day (AHV/day) were estimated to be 147, 427 and 12, 246 respectively. 
Comparative Analysis of Effects of Heavy Vehicles on Roads in Southern and Northern Nigeria

Table 1: Traffic characteristics on Abuja-Kaduna-Kano road

\begin{tabular}{|c|c|c|c|c|c|c|c|c|c|c|c|c|}
\hline \multirow{2}{*}{$\begin{array}{l}\text { Type of } \\
\text { vehicle }\end{array}$} & \multicolumn{2}{|l|}{ Zuba } & \multicolumn{2}{|c|}{ Abuja junction } & \multicolumn{2}{|c|}{ Jos junction } & \multicolumn{2}{|c|}{ Gwargoje } & \multicolumn{2}{|c|}{ Kwankwasiya } & \multicolumn{2}{|l|}{ Total } \\
\hline & $\begin{array}{l}\text { Abuja } \\
\text { bound } \\
66,836\end{array}$ & $\begin{array}{l}\text { Kano } \\
\text { bound } \\
25,522\end{array}$ & $\begin{array}{l}\text { Abuja } \\
\text { bound } \\
48,557\end{array}$ & $\begin{array}{l}\text { Kano } \\
\text { bound } \\
43,257\end{array}$ & $\begin{array}{l}\text { Abuja } \\
\text { bound } \\
18,896\end{array}$ & $\begin{array}{l}\text { Kano } \\
\text { bound } \\
5,260\end{array}$ & $\begin{array}{l}\text { Abuja } \\
\text { bound } \\
52,520\end{array}$ & $\begin{array}{l}\text { Kano } \\
\text { bound } \\
36,010\end{array}$ & $\begin{array}{l}\text { Abuja } \\
\text { bound } \\
48,972\end{array}$ & $\begin{array}{l}\text { Kano } \\
\text { bound } \\
39,786\end{array}$ & $\begin{array}{l}\text { Abuja } \\
\text { bound } \\
235,781\end{array}$ & $\begin{array}{l}\text { Kano } \\
\text { bound } \\
\text { 149,835 }\end{array}$ \\
\hline $\begin{array}{l}\text { Passenge } \\
\text { r cars }\end{array}$ & 126,725 & 147,537 & 142,459 & 139,808 & 73,037 & 72,710 & 100,996 & 96,912 & 67,798 & 57,948 & 511,015 & 514,915 \\
\hline $\begin{array}{l}\text { Mini } \\
\text { buses/pi } \\
\text { ck ups }\end{array}$ & 36,076 & 60,321 & 54,746 & 50,602 & 34,919 & 38,445 & 61,970 & 44,817 & 58,350 & 42,742 & 246,061 & 234,927 \\
\hline $\begin{array}{l}\text { Heavy } \\
\text { vehicles }\end{array}$ & 23,591 & 26,868 & 13,980 & 17,442 & 11,731 & 5,718 & 19,039 & 17,163 & 18,974 & 16,930 & 87,322 & 84,121 \\
\hline \multicolumn{13}{|c|}{$\begin{array}{l}\text { Total Traffic Volume on both directions }=2,063,977 \\
\text { Average Daily Traffic }(\text { ADT })=147,427\end{array}$} \\
\hline $\begin{array}{l}\text { Total no. o } \\
\text { Heavy veh } \\
\text { Overall pe }\end{array}$ & $\begin{array}{l}\text { heavy vel } \\
\text { cle (HV)/d } \\
\text { centage of }\end{array}$ & $\begin{array}{l}\text { icles }=171 \\
y=12,24 \\
\text { heavy vehi }\end{array}$ & $\begin{array}{l}443 \\
\text { les }=8.3\end{array}$ & & & & & & & & & \\
\hline
\end{tabular}

\section{Traffic characteristics of Port Harcourt-Enugu road}

The effect of heavy vehicles on flexible pavement was investigated using Port Harcourt-Enugu road as a case study, the summary of traffic characteristics on the road is presented in Table 2. It could be observed from Table 2 that a total of 750,381 vehicles were counted, indicating a total traffic volume on both directions. Motorcycles, passenger cars, mini-buses/pick-ups and heavy vehicles constitute 4.6\% (34,605), $30.1 \%(226,191), 26.2 \%(196,261)$ and $39.1 \%(293,324)$ of the total traffic volume respectively. The average daily traffic (ADT) and average heavy vehicles per day (AHV/day) were estimated to be 53,670 and 20,951 respectively.

Table 2: Traffic Characteristics on Port Harcourt-Enugu road

\begin{tabular}{|c|c|c|c|c|c|c|c|c|c|c|c|c|}
\hline \multirow[t]{2}{*}{$\begin{array}{l}\text { Type of } \\
\text { vehicle }\end{array}$} & \multicolumn{2}{|c|}{$\begin{array}{l}\text { Ndiagu Amechi, } \\
\text { Enugu }\end{array}$} & \multicolumn{2}{|c|}{ Ishiagu junction } & \multicolumn{2}{|l|}{ Okigwe } & \multicolumn{2}{|c|}{ Osisioma, Aba } & \multicolumn{2}{|c|}{ Rumuigbo } & \multicolumn{2}{|l|}{ Total } \\
\hline & $\begin{array}{l}\text { Port } \\
\text { Harco } \\
\text { urt } \\
\text { bound }\end{array}$ & $\begin{array}{l}\text { Enugu } \\
\text { bound }\end{array}$ & $\begin{array}{l}\text { Port } \\
\text { Harcourt } \\
\text { bound }\end{array}$ & $\begin{array}{l}\text { Enugu } \\
\text { bound }\end{array}$ & $\begin{array}{l}\text { Port } \\
\text { Harcourt } \\
\text { bound }\end{array}$ & $\begin{array}{l}\text { Enugu } \\
\text { bound }\end{array}$ & $\begin{array}{l}\text { Port } \\
\text { Harcourt } \\
\text { bound }\end{array}$ & $\begin{array}{l}\text { Enugu } \\
\text { bound }\end{array}$ & $\begin{array}{l}\text { Port } \\
\text { Harcourt } \\
\text { bound }\end{array}$ & $\begin{array}{l}\text { Enugu } \\
\text { bound }\end{array}$ & $\begin{array}{l}\text { Port } \\
\text { Harcourt } \\
\text { bound }\end{array}$ & $\begin{array}{l}\text { Enugu } \\
\text { bound }\end{array}$ \\
\hline $\begin{array}{l}\text { Motorcycle } \\
\text { s }\end{array}$ & 3,096 & 3,559 & 3,928 & 4,528 & 3,503 & 3,549 & 2,661 & 3,140 & 3,310 & 3,331 & 16,498 & 18,107 \\
\hline $\begin{array}{l}\text { Passenger } \\
\text { cars }\end{array}$ & 40,842 & 40,592 & 20,977 & 20,673 & 14,775 & 13,088 & 12,630 & 13,414 & 25,518 & 23,682 & 114,742 & 111,449 \\
\hline $\begin{array}{l}\text { Mini } \\
\text { buses/pick } \\
\text { ups }\end{array}$ & 23,088 & 26,282 & 21,793 & 24,609 & 14,381 & 14,000 & 15,522 & 13,784 & 21,866 & 20,936 & 96,650 & 99,611 \\
\hline $\begin{array}{l}\text { Heavy } \\
\text { vehicles }\end{array}$ & 32,690 & 31,672 & 27,223 & 30,112 & 32,286 & 33,504 & 30,678 & 30,884 & 24,457 & 19,812 & 147,334 & 145,990 \\
\hline $\begin{array}{l}\text { Total Traffic } \\
\text { Average Dail } \\
\text { Total no. of } h \\
\text { Heavy vehicl } \\
\text { Overall perce }\end{array}$ & $\begin{array}{l}\text { Volume o } \\
\text { Traffic } \\
\text { eavy vehi } \\
(\mathrm{HV}) / \mathrm{da} \\
\text { tage of } \mathrm{h}\end{array}$ & $\begin{array}{l}\text { both dir } \\
\text { ADT })=5 \\
\text { les }=293 \\
=20,952 \\
\text { avy vehic }\end{array}$ & $\begin{array}{l}\text { tions }=750 \\
670 \\
324 \\
\text { es }=39.1 \%\end{array}$ & 381 & & & & & & & & \\
\hline
\end{tabular}

\section{Effect of heavy axles on Abuja-Kaduna-Kano Road}

The overall equivalent single axle load on Abuja-Kaduna-Kano road was estimated to be 548,676 in 14 days according to AASHTO Design Guideline. However, from the analysis from Table 3, an average heavy vehicle on the expressway possesses an average equivalent factor of 3.43 which is approximately three 
LAUTECH Journal of Civil and Environmental Studies

Volume 7, Issue 1; September, 2021

times the standard axle weight for road pavement. This indicates that an average truck on the road caused the same pavement damage as almost three and a half standard axles of $80 \mathrm{kN}$ would cause. It shows there is a high degree of overloading on the road which is one of the major causes of pavement deterioration. However, the percentage of heavy vehicles causing this structural damage to pavement is $8.31 \%$. A total of 171,443 heavy vehicles (trucks) of various categories were counted, each possessing an average equivalent factor of 3.43 for the fourteen days of survey. This implies that on the average, each heavy vehicle on Abuja-Kaduna-Kano road causes three times the damage of the standard weight legally permitted on the pavement of Nigerian roads. The computed value is high and excessive and constitutes one of the major reasons for deterioration of road pavements along Abuja-Kaduna-Kano expressway.

\section{Effect of heavy axles on Port Harcourt-Enugu road}

The overall equivalent single axle load on Port Harcourt-Enugu Road was estimated to be 836,208 in 14 days according to AASHTO Design Guideline. However, from the analysis from Table 4, an average heavy vehicle on the expressway possesses an average equivalent factor of 3.02 which is approximately three times the standard axle weight for road pavement. This indicates that an average truck on the road caused the same pavement damage as almost three and a half standard axles of $80 \mathrm{kN}$ would cause. It shows there is a high degree of overloading on the road, which is one of the major causes of pavement deterioration. However, the percentage of heavy vehicles causing this structural damage to pavement is $39.1 \%$.

A total of 293,324 heavy vehicles (trucks) of various categories were counted, each possessing an average equivalent factor of 3.02 for the fourteen days of survey. This implies that on the average, each heavy vehicle on Port Harcourt-Enugu Road causes three times the damage of the standard weight legally permitted on the pavement of Nigerian roads. The computed value is high and excessive and constitutes one of the major reasons for deterioration of road pavements along Abuja-Kaduna-Kano expressway.

However, this study confirms the assertion made by axle load draft report of FMW (2007) where an axle load study carried out in 2005/2006 revealed that larger number of heavy vehicles were plying coastal roads compared to the hinterlands, which was adduced to reasons why more roads in coastal and southern parts of the country were in worse state as compared to roads in the northern extremities of the country. The total number of vehicles and heavy vehicles between Abuja and Kano were estimated to 2,063,977 and 171,443 respectively as against Port Harcourt and Enugu with estimated total number of all vehicles and heavy vehicles of 750,381 and 293,324 respectively. It could be seen that the percentage of trucks to total vehicles per day were $39.1 \%$ and $8.31 \%$ on Port Harcourt-Enugu and Abuja-Kano roads respectively. The percentage of light vehicles on Abuja-Kaduna-Kano road and Port Harcourt-Enugu were $92 \%$ and $61 \%$ respectively. This could be responsible for the more structural stability of Abuja-Kano road when compared with Port Harcourt-Enugu road in terms of levels of deterioration. 
Table 3: Distribution of Equivalent Number of Vehicle Axle Load on Abuja -Kano Road according to AASHTO Design Guideline, 1993

\begin{tabular}{|c|c|c|c|c|c|c|c|c|c|c|c|c|c|c|}
\hline \multirow{2}{*}{$\begin{array}{l}\text { Category } \\
\text { Of vehicle/No. } \\
\text { of Axle }\end{array}$} & \multirow[t]{2}{*}{ Code } & \multirow{2}{*}{$\begin{array}{l}\text { Total load } \\
\text { Axles } \\
\text { Distribution } \\
\text { (ton) }\end{array}$} & \multicolumn{2}{|c|}{ Total no. of vehicles } & \multicolumn{6}{|c|}{ Load Equivalency Factor (LEF per vehicle) } & \multirow{2}{*}{$\begin{array}{l}\text { Total load } \\
\text { equivalency } \\
\text { factor }\end{array}$} & \multirow{2}{*}{$\begin{array}{l}\text { LEF*No. of } \\
\text { vehicle }\end{array}$} & \multicolumn{2}{|l|}{$\begin{array}{l}\text { Average LEF } \\
\text { (All vehicles) }\end{array}$} \\
\hline & & & $\begin{array}{l}\text { Kano } \\
\text { bound }\end{array}$ & $\begin{array}{l}\text { Abuja } \\
\text { bound }\end{array}$ & Axle 1 & Axle 2 & Axle 3 & Axle 4 & Axle 5 & Axle 6 & & & $\begin{array}{l}\text { Abuja } \\
\text { bound }\end{array}$ & \\
\hline Truck 2 Axle & $1-2$ & 16 & 29,132 & 25,321 & 0.2923 & 2.2555 & & & & & 2.5478 & 74,223 & 64,513 & 3.43 \\
\hline Truck 3 Axle & $1-2.2$ & 24 & 21,888 & 19,813 & 0.2923 & 2.0362 & & & & & 2.3285 & 50,966 & 46,135 & \\
\hline Truck 4 Axle & $1-2.2 .2$ & 27 & 1,832 & 2,396 & 0.2923 & 0.2923 & 2.0362 & & & & 2.6208 & 4,801 & 6,279 & \\
\hline Truck 4 Axle & $1-2-2.2$ & 34 & 15,630 & 21,875 & 0.2923 & 2.2555 & 2.0362 & & & & 4.584 & 71,648 & 100,275 & \\
\hline Truck 5 Axle & $1-2.2-2.2$ & 42 & 1,035 & 958 & 0.2923 & 2.0362 & & 2.0362 & & & 4.3647 & 4,517 & 4,181 & \\
\hline Truck 5 Axle & $1-1-2.2 .2$ & 33 & 7,904 & 9,438 & 0.2923 & 2.2555 & 1.3598 & & & & 3.9076 & 30,886 & 36,880 & \\
\hline Truck 6 Axle & $1-2.2-2.2 .2$ & 45 & 6,700 & 7,514 & 0.2923 & 2.0362 & & 1.3598 & & & 3.6883 & 24,712 & 27,714 & \\
\hline
\end{tabular}

1 - Single wheel single axle

2 - Double wheel single axle

2.2 - Double wheel double axle

2.2.2 - Double wheel triple axle
The Equivalent Single Axle Load (ESAL) on Kano bound $=\mathbf{2 6 1 , 7 5 3}$

The Equivalent Single Axle Load (ESAL) on Abuja bound $=\mathbf{2 8 5 , 9 7 7}$

The overall ESAL on Abuja -Kaduna - Kano Road = 547,730

Table 4: Distribution of Equivalent Number of Vehicle Axle Load on Port Harcourt-Enugu Road according to AASHTO Design Guideline, 1993.

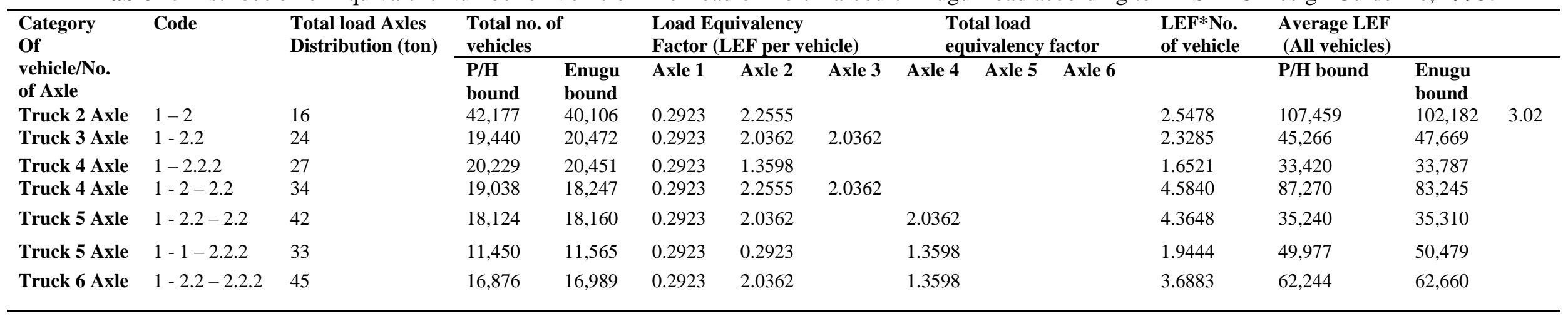

1 - Single wheel single axle 2 - Double wheel single axle

2.2 - Double wheel double axle

2.2.2 - Double wheel triple axle
The Equivalent Single Axle Load (ESAL) on Port Harcourt bound $=\mathbf{4 2 0 , 8 7 6}$

The Equivalent Single Axle Load (ESAL) on Enugu bound $=\mathbf{4 1 5 , 3 3 2}$

The overall ESAL on Abuja -Kaduna - Kano Road = 836,208 
LAUTECH Journal of Civil and Environmental Studies

Volume 7, Issue 1; September, 2021

\section{Conclusion}

The Comparative Analysis of Effects of Heavy Vehicles on Roads in Southern and Northern Nigeria was carried out and the following conclusions could be drawn;

1. An average Load Equivalency Factors (LEFs) of 3.43 and 3.02 were estimated for each heavy vehicle plying the Northern and Southern roads respectively. That is, each heavy vehicle that plies these roads has same damaging effect as approximately three standard axle load of $80 \mathrm{kN}$. Obviously these roads are overstretched as they are being subjected to loading beyond permitted legal limit of standard axles.

2. The failures noticed on these roads such as alligator cracks, potholes, depression, longitudinal cracks along the centre-line were more pronounced on Port Harcourt-Enugu road owing to higher volume of heavy vehicles (39.1\%) to Abuja-Kano (8.31\%). These failures could be as a result of/or combination of factors and not limited to overloading from heavy trucks. The factors could include poor or unstable Subgrade, Subbase, Base and asphaltic materials, lack of proper supervision or poor-quality control measures, lack of proper maintenance culture, lack of proper compaction to mention but a few.

\section{Recommendations}

It is highly recommended that weigh bridges should be introduced on all highways in Nigeria in order to ensure that maximum allowable load limits in service do not exceed the design provisions as this has been majorly responsible for the deplorable states or premature failures of most Nigerian roads. It is also recommended that a policy or law should be enacted by government to criminalize overloading beyond legal limits on Nigerian roads and appropriate sanctions be meted out to offenders. This will go a long way in reducing premature flexible pavement failures due to heavy vehicles and in turn bring sanity to the roads by reducing accidents and travel times caused as a result of bad roads. Further studies are recommended considering other factors such poor or unstable subgrade, subbase, base and asphaltic materials, poor quality control measures, lack of proper maintenance culture to mention but few that could also be responsible for premature failures of Nigerian roads in order to have a holistic conclusion and recommendations as to the cause and solutions of premature failures of roads in Nigeria.

\section{References}

AASHTO, 1993. AASHTO Guide for Design of Pavement Structures, Washington, D.C

Gillespie, T.D., Karamihas, S.M., Cebon, D., Sayers, M.W., Nasim, M.A., Hansen, W., and N. Ehsan (1993). "Effects of Heavy Vehicle Characteristics on Pavement Response and Performance" Journal: National Cooperative Highway Research Program Report, No. 353, pp. 1- 126

Hudson, W.R., Monismith, C.L., Dougan, C.E., and Visser, W. (2003). "Use Performance Management System Data for Monitoring Performance: Example with Superpave, Transportation Research Record 1853, TRB, Washington D.C

Kadyali, L.R and Lal, N.B. (2008). "Principles and practice of Highway Engineering. Pp 313-393. Romesh Chanderkhan, Delhi $5^{\text {th }}$ Ed.

Koesdarwanto (2004). "Evaluation of Flexible Pavement Service Life as a Function of Overloaded Vehicles, Thesis, Surakarta Muhammadiyah University (UGM), Yogyakarta

Matawal, D.S., Aitsebaomo, F.O., Osadebe, C.C., Quadri, H.A. (2018) "Road Pavement Failure Investigation of Abuja-Kaduna-Kano Road" NBRRI Technical Report No. 44, pp. 1 - 66

Mc Elvaney, J. and Snaith, M.S. (2005). "Analytical Design of Flexible Pavements, In Highways: location, design, construction and maintenance of pavements. Ed: O'Flaherty, C.A. pp 395-419

Ndoke, P.N (2013). "Influence of Axle Load on Road Pavement in Nigeria". Proceedings of National Conference on Road Pavement Failure in Nigeria held at Nicon Luxury Hotel, Abuja, Nigeria. $7^{\mathrm{TH}}-9^{\mathrm{TH}}$ May, 2003. pp. 115-125 
Oduola, R.O (2010) "Engineering Potentials of Industrial Waste Materials in Low Cost and Durable Flexible Pavement Construction in Nigeria. Conference Proceedings and Annual General Meetings, Nigerian Institution of Civil Engineers (NICE).

Osadebe, C.C., Fakeye, A.M., Matawal, D.S., Aitsebaomo, F.O. (2013) "Road Pavement Failure: A Case Study of Enugu-Port Harcourt Expressway". Proceedings of National Conference on Road Pavement Failure in Nigeria held at Nicon Luxury Hotel, Abuja, Nigeria between $7^{\text {th }}-9^{\text {th }}$ May 2013, pp. 63-85

Pais, J.C; Amorim, S.I.R., Minhoto, M. (2013) "Impact of Traffic Overload on Road Pavement Performance" Journal of Transportation Engineering, Vol. 139, Issue No. 9, pp. 873-879

Parsley, L.L and Ellis, S.D. (2003). "Guidelines for short period traffic counts in developing countries". Project Report PR/INT/270/2003. Crowthorne

Raheel, M., Khan, R., Khan, A., Khan, M.T., Ali, I., Alam, B. and Wali, B. (2018). Impact of axle overload asphalt pavement thickness and subgrade modulus on load equivalency factor using modified ESALs equation. Journal of Cogent Engineering, Vol. 5, Issue No. 1

Rahim (2000). Analysis of Road Damage Due to Overloading on Causeway in Eastern Sumatra Riau Province. Thesis-S2, Master System and Transportation Engineering, Gajahmada University (UGM), Yogyakarta

Savio, D., Nivitha, M.R., Bindhu, B.K., and Krishnan, J.M. (2016). Overloading analysis of bituminous pavements in India using M-EPDG. Transportation Research Procedia 17 (2016), pp. 607-616

Sulisty, B.S. and Handayani, C. (2002). The effect of heavy vehicle's overloading to the pavement damage/service life, thesis, Department of Civil Engineering University of Diponegoro Semarang, Indonesia

Tijani, M.A., Akinleye, M., and Folake, J.K. (2017). Engineering Properties of Laterites Obtained in Ede, Southwestern Nigeria. Nigerian Journal of Technology (NIJOTECH), Vol. 36, No.2, pp. 386-394

Titi, H.H; Coley, N.J., and Latifi, V. (2018). Evaluation of Pavement Performance due to Overload SingleTrip Permit Truck Traffic in Wisconsin. Advances in Civil Engineering, Volume 2018, Article ID 1070653, pp. 1-11

Yu, H.T., Khazanovich, L., Darter, M.I., and Ardani, A. (1998). Analysis of Concrete Pavement Responses to Tempertaure and Wheel Load Measured from Instrunmented Slabs. Journal of Treansportation Research Record, 1639, Transportation Research Board, National Research Council, Washington, D.C., pp. 94-101

Zumrawi, M. (2016). Investigating Causes of Pavement deterioration in Khartoum State. International Journal of Civil Engineering and Technology, Vol. 7, Issue No. 72, pp. 203-214 